\title{
KAJIAN OPTIMALISASI PEMANFAATAN CSR UNTUK KEGIATAN PRODUKTIF DALAM UPAYA MENINGKATKAN KESEJAHTERAAN MASYARAKAT DI PROVINSI KALIMANTAN TENGAH
}

\section{Optimization Review Of CSR Utilization For Productive Activities In Efforts To Improve People's Welfare In Central Kalimantan Province}

\section{Muhamad Yusuf* \\ Raden Biroum \\ Bernandianto \\ Farid Zaky Yopiannor \\ Muhammad Jailani}

\begin{abstract}
Universitas Muhammadiyah Palangkaraya, Palangka Raya, Central Kalimantan, Indonesia
\end{abstract}

email:

yusuf.quratayun@gmail.com

\section{Kata Kunci: \\ Kajian \\ Optimalisasi \\ Tanggung Jawab Sosial \\ Kesejahteraan Masyarakat}

\section{Keywords: \\ Study \\ Optimization \\ Social responsibility \\ Community Welfare}

\section{Accepted \\ January 2018}

Published

April 2018

\begin{abstract}
Abstrak
Penelitian ini bertujuan untuk mengakaji optimalisasi pemanfaatan CSR untuk kegiatan produktif dalam upaya meningkatkan sejahteraan masyarakat di Provinsi Kalimantan Tengah. Kajian ini dilakukan karena pemerinah sadar tidak akan mempu membiayai seluruh kegiatan pembangunan dengan konsidi pertumbuhaan ekonomu yang belum maksimal. Untk itu, peningkatan kerjasama pemerintah dan swasta yang lebih sistematik dan berkelanjutan perlu dikebangkan dan dioptimalkan salah satunnya melalui skema pemanfataan dana tanggung jawab sosial perusahaan atau Coprorate Social responsibility (CSR).

Penelitian ini menggunakan pendekatan pendekatan metode kualitatif yang didukung dengan data kuantitatif. Pendekatan kualitatif diasumsikan relevan untuk menjaring seluruh pandangan stakeholders terkait CSR. Studi akan mengambil Kabupaten Kotawaringin Timur sebagai objek kajian. Kabupaten Kotawaringin Timur sudah memiliki Perda yang mengatur CSR dan memiliki kelembagaan berupa forum CSR. Pemilihan objek kajian ini juga didasarkan pada beberapa pertimbangan praktis terkait dengan potensi ketersediaan dan akses data serta banyaknnya Perusahaan yang ada di Kabupaten Kotawaringin Timur dalam lingkungan Pemerintah Provinsi Kalimantan Tengah.

Hasil kajian ini menunjukkan Kebijakan CSR oleh Pemerintah Kabupaten Kotawaringin Timur dalam tataran implementasi masih lemah. Hal ini diakibatkan kurang adanya kesepahaman antar stakeholder dalam memahami tata kelola CSR yang baik dan berkelanjutan. Amanat dari Peraturan Daerah No.2I tahun 2014 Kabupaten Kotawaringin Timut tentang CSR adalah pembentukan Forum CSR. Namun demikian dalam perjalanannya Forum CSR belum bisa bergerak secara fleksibel karena keterbatasan program kerja dan anggaran. Sehingga Forum CSR sampai dengan sekarang belum bisa secara optimal menjembatani pemerintah dengan pihak perusahaan terkait tata kelola program CSR.
\end{abstract}

\begin{abstract}
This research aims to families the optimization of CSR for productive activities in the effort to increase the Community's welfare in the province of Central Kalimantan. This study is done because Pemerinah aware will not be able to finance all development activities with the economic growth that is not maximized. That is the increase of government and private cooperation that is more systematic and sustainable need to be flown and optimized for misalignment through the scheme of fund-raising of Corporate Social responsibility (CSR).

This study uses a qualitative method approach that is supported by quantitative data. The qualitative approach is assumed to be relevant to capture the entire stakeholder's view of CSR. The study will take East Kotawarakan regency as the object of study. East Kotawarwants Regency already has a Perda that regulates CSR and institutional of CSR Forum. The selection of the object of this study is also based on some practical considerations related to the potential availability and access to data and many of the companies in the East Kotawarwants regency in the Central Kalimantan provincial government environment.

The results of this study showed the CSR policy by the East Kotawarwants District government in the implementation of weak. This is due to the lack of understanding between stakeholders in understanding good and sustainable CSR governance. The mandate from local regulation No. 2I, 2014 Regency of Kotawarwant Timut about CSR is the establishment of CSR Forum. However, in its journey, the CSR forums have not been able to move flexibly due to limited employment and budget programs. So that the CSR Forum until now can not optimally bridge the government with the company related to the governance of the CSR program.
\end{abstract}




\section{PENDAHULUAN}

Derap langkah pembangunan Kalimantan Tengah di masa depan semakin besar dalam rangka meningkatkan daya saing terhadap provinsi-provinsi lainnya. Dalam rangka mewujudkan hal tersebut Pemerintah Provisi Kalimantan Tengah berupaya keras meningkatkan pembangunan di segala bidang. Namun disadari bersama bahwa gerak pembangunan memerlukan biaya yang tidak sedikit, disisi lain kemampuan pembiayaan pembangunan pemerintah relatif terbatas. Pertumbuhan ekonomi yang dicita-citakan, faktanya belum mampu menghasilkan efek menetes ke bawah (trickle down effect) untuk meningkatkan kesejahteraan rakyat. Pemerintah Kalimantan Tengah, melalui motto Kalteng Berkah, menjadi motor penggerak (driven force) pembangunan dalam bentuk sebagai pelaku langsung dan atau dengan jalan menciptakan peluang di berbagai bidang melalui penetapan kebijakan regulasi yang dapat menarik investasi.

Pemerintah sadar tidak akan mampu membiayai seluruh kegiatan pembangunan dengan kondisi pertumbuhan ekonomi yang belum maksimal. Partisipasi sektor swasta dalam mencapai tujuan pembangunan merupakan sebuah keniscayaan menjadi alternatif pilihan rasional. Upaya mengoptimalkan sumber pendanaan Non-APBD dan non-APBN dapat menjadi solusi potensial meringankan beban pembangunan daerah. Untuk itu, peningkatan kerja sama pemerintah dan swasta yang lebih sistematik dan berkelanjutan perlu dikembangkan dan dioptimalkan, salah satu diantaranya melalui skema pemanfaatan dana tanggung jawab sosial perusahaan Corporate Social Responsibility (selanjutnya ditulis CSR).

Suharto (2006) mengatakan bahwa dalam konteks global, istilah CSR mulai digunakan sejak tahun 1970-an dan semakin populer terutama setelah Elkington (1997) mengembangkan tiga komponen penting Pembangunan Berkelanjutan (Sustainable Development), yakni pertumbuhan ekonomi (economic growth), perlindungan lingkungan (environmental protection), dan keadilan sosial (social equity). Elkington mengemas CSR ke dalam tiga fokus: $3 \mathrm{P}$, singkatan dari profit, planet dan people. Perusahaan yang baik tidak hanya memburu keuntungan ekonomi belaka (profit). Melainkan pula memiliki kepedulian terhadap kelestarian lingkungan (planet) dan kesejahteraan masyarakat (people).

Potensi dana CSR di Kalimantan Tengah sebenarnya cukup besar, mengingat banyaknya investor yang menanamkan investasinya. Sektor perkebunan merupakan salah satu bidang investasi yang menjadi leading sector saat ini. Pengembangan subsektor perkebunan merupakan salah satu prioritas program pembangunan daerah Provinsi Kalimantan Tengah, dalam rangka optimalisasi pemanfaatan potensi SDA serta nilai tambah dan efek berganda positif (multiplier effect) bagi pertumbuhan ekonomi daerah, kemakmuran rakyat dan kelestarian lingkungan hidup. Tercatat perkebunan kelapa sawit yang dieksplorasi oleh perkebunan besar sebanyak 34I unit dengan luas 4.068.022 ha (Sumber: Indonesian Development Forum, 2017).

Pada kenyataannya tantangan mendasar yang dihadapi Pemerintah sekarang ini adalah bahwa investasi tersebut masih belum memberikan kontribusi yang siginifikan terhadap peningkatan kesejahteraan masyarakat di Kalimantan Tengah. Sumber Daya Alam (SDA) yang melimpah belum dapat memberikan nilai tambah optimal bagi kepentingan masyarakat Kalimantan Tengah. Hamparan hutan yang luas beserta kekayaan mineral, flora dan fauna didalamnya yang dimiliki belum mampu membawa kesejahteraan bagi masyarakat.

Pelaksanaan CSR di sektor perkebunan cenderung masih berada pada tahap pembagian keuntungan yang dipergunakan untuk menjawab gejolak lingkungan sekitar atau hanya sebagai 'pemadam' sementara masyarakat yang merasakan dampak kehadiran perusahaan. Pelaksanaan program 
CSR yang dilakukan selama ini dilakukan berdasarkan pemahaman yang dimiliki oleh perusahaan, imparsial dan cenderung berjalan sendiri-sendiri. Berdasarkan pemahaman awal dari perusahaan boleh jadi mereka sudah melaksanakan program tersebut namun kendalanya adalah tidak efektif dan cenderung tidak tepat sasaran, koordinasinya masih lemah dan dampak yang masih belum signifikan membentuk kemandirian pada masyarakat. Hal tersebut bisa jadi karena pendekatan CSR yang dipakai masih terjebak pada pola yang bersifat karitatif dan charity, sekali membantu, setelah itu selesai. Program seperti ini tidak akan berkelanjutan dan justru mencipatakan mentalitas meminta bagi masyarakat sasaran program.

Konsep pemberdayaan sangat penting untuk memberikan perspektif positif terhadap orang miskin yang dipandang sebagai orang yang serba kekurangan. Melalui pemberdayaan masyarakat dapat mewujudkan penyediaan sumber daya, kesempatan, pengetahuan, dan keterampilan bagi masyarakat. Maka, melalui kajian ini akan mencoba mengidentifikasi dan menggali lebih mendalam bagaimana pelaksanaan program CSR di Kabupaten Kotawaringin Timur. Kajian ini juga akan menelaah lebih mendalam terkait peluang integrasi program CSR dengan program pembangunan daerah serta potensi program tersebut menjadi role model pemanfaatan CSR perusahaan-perusahaan di Provinsi Kalimantan Tengah.

\section{METODOLOGI}

Penelitian ini menggunakan pendekatan pendekatan metode kualitatif yang didukung dengan data kuantitatif. Pendekatan kualitatif diasumsikan relevan untuk menjaring seluruh pandangan stakeholders terkait CSR. Studi akan mengambil Kabupaten Kotawaringin Timur sebagai objek kajian. Kabupaten Kotawaringin Timur sudah memiliki Perda yang mengatur CSR dan memiliki kelembagaan berupa forum CSR. Pemilihan objek kajian ini juga didasarkan pada beberapa pertimbangan praktis terkait dengan potensi ketersediaan dan akses data. Kemudahan tersebut menyebabkan penelitian ini berjalan dengan efisien berdasarkan waktu dan biaya yang telah ditetapkan.

Sumber data kajian dikumpulkan dari pemangku kepentingan yang terkait dengan pelaksanaan CSR, yaitu Pemerintah Kabupaten Kotawaringin Timur, DPRD Kabupaten Kotawaringin Timur, Badan usaha, Asosiasi pengusaha perkebunan, masyarakat dan Forum CSR Kabupaten atau Provinsi. Data juga diperoleh dari kelembagaan CSR yang sudah berjalan dan bisa menjadi rujukan (best practice), data juga didukung dengan literatur terbaru tentang konsep dasar dan prinsip CSR.

\section{HASIL DAN PEMBAHASAN}

Temuan pada praktik CSR oleh beberapa Perusahaan Perkebunan swasta di lokasi penelitian menunjukan bahwa komitmen perusahaan perkebunan swasta di Kabupaten Kotawaringin Timur terhadap pemangku kepentingan (stakeholder) khususnya masyarakat terdekat wilayah operasional cukup besar. Perusahaan terus berupaya meningkatkan program CSR untuk menciptakan hubungan kerjasama yang harmonis dan berkesinambungan dengan lingkungan sekitar. CSR bagi perusahaan merupakan tanggungjawab sosial perusahaan terhadap peningkatan nilai dan kualitas hidup stakeholder sehingga penting untuk terus berupaya meningkatkan manfaat bagi karyawan, supplier, konsumen, media massa, dunia pendidikan dan tentu saja yang utama adalah masyarakat desa binaan.

Implementasi konsep Triple Bottom Line pada Program CSR dalam penelitian ini, berdasarkan indikator jenis program kegiatan dan asas keberlanjutan atau sustainibility serta manfaatnya bagi stakeholders, menunjukan bahwa kegiatan-kegiatan CSR yang telah dilaksanakan secara umum telah mencakup keadilan pada tiga unsur utama yaitu profit, people dan planet serta aspek keberlanjutan 
program yang dinilai telah sesuai dengan prinsip pembangunan keberlanjutan, yang menyebutkan bahwa manusia dan lingkungan merupakan bagian yang integral dalam sebuah roda perputaran bisnis perusahaan.

Tanggung jawab ekonomi (Profit) Perkebunan Besar Sawit di Kotawaringin Timur selaku pihak investor tetap mengedepankan unsur bisnis. Kepedulian social perusahaan merupakan bagian dari usaha menjaga stabilitas hubungan dengan masyaraat sosial setempat dalam rangka menjamin situasi investasi yang kondusif yang pada akhirnya akan menghasilakan profit bagi perusahaan.

Terhadap perspektif tanggung jawab lingkungan (Planet), program-program CSR Perusahan Besar Sawit bidang lingkungan secara nyata telah banyak dilakukan untuk menyelamatkan dan melestarikan lingkungan. Mereka berkomitmen mewujudkan kelapa sawit lestari (sustainable palm oil). Kegiatan standarisasi praktek operasional sesuai Prinsip dan Kriteria Roundtable On Sustainable Palm Oil (RSPO) senantiasa diterapkan. Beberapa perusahaan berpandangan bahwa mereka tidak sekadar membangun perkebunan, melainkan membangun masyarakat perkebunan di Indonesia, bersama dengan para petani kelapa sawit yang merupakan mitra usaha. Temuan lain di lapangan juga menunjukan bahwa upaya untuk selalu memberikan produk yang berkualitas dengan efektif dan efisien dilakukan dengan memberdayakan seluruh karyawan melakukan inovasi dan perbaikan berkesinambungan secara terstruktur dengan menerapkan Total Quality Management. Hal ini merujuk kepada menuju cita-cita "Menjadi Perusahaan Berkelas Dunia" yang diterjemahkan kedalam 3 kategori yaitu berkelas dunia dalam praktek pengelolaan perkebunan, organisasi dan komitmen.

Tanggung jawab sosial (people) secara nyata dilaksanakan oleh Perusahaan Besar Sawit sebagai obyek penelitian melalui aktifitas CSR bidang pendidikan, kesehatan, program kemitraan serta infrastruktur dan bencana. Beberapa praktik CSR yang dilakukan selama ini pada dasarnya menggambarkan bahwa kepedulian dari sisi social berjalan cukup baik.

\section{A. Kebijakan CSR Kotawaringin Timur}

Khusus Pemerintah Kabupaten Kotawaringin Timur merespon CSR dengan mengeluarkan Peraturan Daerah Nomor 2l Tahun 2014 dan Peraturan Bupati yang secara khusus mengatur pelaksanaan CSR.

Perda tersebut dianggap sangat akomodatif karena akan membantu pemerintah Kabupaten Kotawaringin timur dalam rangka melaksanakan pembangunan dengan dukungan program-program CSR dimana Kabupaten Kotawaringin Timur merupakan kabupaten yang paling banyak perusahaan besar swasta sektor perkebunan beroperasi. Hal tersebut menunjukan ada potensi besar yang bisa diperoleh dari dana CSR perusahaan yang ada di Kabupaten Kotawaringin Timur khususnya sektor perkebunan untuk membantu dan mendukung pemerinah dalam membangun masyarakat melalui program-program yang kadangkala tidak cukup ter-cover dengan APBD Kotawaringin Timur.

Berdasarkan hasil observasi motivasi pembuat kebijakan yaitu Dewan Permusyawaratan Rakyat Daerah (DPRD) Kabupaten Kotawaringin Timur dalam perumusan PERDA ini adalah untuk mengakomodasi segala kepentingan shareholder maupun stakeholder yang ada di Kotawaringin Timur. Dalam persepktif ini juga bisa dilihat kemunculan PERDA karena Kotawaringin Timur merupakan kabupaten dengan iklim investasi yang sangat baik, hal ini bisa dilihat bahwa di Kotawaringin Timur terdapat banyak perusahaan besar swasta sektor perkebunan

Realitas di Kabupaten Kotawaringin Timur untuk mengajak peran serta dunia usaha dalam 
mensinergikan dengan program pemerintah menjadi tantangan tersendiri, sebab praktik CSR yang dlaksanakan oleh perusahaan masih berorientasi pada lingkungannya sendiri dan masih terjebak pada aspek pencitraan (branding) perusahaan saja. Pola perusahaan dalam praktk CSR lebih pada 'tebar pesona' daripada 'tebar karya'. Sehingga untuk mengarahkan program CSR, kepada masalah-masalah sosial (pendidikan, kesehatan, kebudayaan) belum banyak perusahaan yang perhatian ke arah sana dikarenakan masih terjadi multitafsir dari berbagai stakeholder terkhusus perusahaan dalam memahami peraturan terkait CSR yang telah diterbitkan oleh pemerintah.

Berdasarkan hasil observasi dan wawancara Peraturan Daerah (PERDA) yang sudah diterbitkan oleh Pemerintah ini masih belum bisa berjalan optimal. Para stakeholder terkait masih sama-sama mencari pola yang tepat dalam pengelolaan program CSR. Sehingga setelah beberapa tahun PERDA ini belum memberikan kontribusi positif terkait pengelolaan program CSR di Kotawaringin Timur. Karena memang di dalam PERDA tersebut belum mengatur secara jelas mengenai sanksi yang diberikan kepada pihak perusahaan yang tidak melaksanakan program CSR.

B. Faktor-Faktor yang Mempengaruhi pelaksanana Program CSR

Praktik pelaksanaan program CSR di Kabupaten Kotawaringin Timur selama ini masih belum dapat dikatakan tepat guna dan tepat sasaran. Pelaksanaan CSR masih masih menghadapi beberapa kendala, seperti tidak semua perusahaan membuat laporan pelaksanaan CSR secara transparan kepada pemerintah. Hal terebut berdampak pada sulitnya koordinasi dan sinkronisasi program antara pemerintah dengan perusahaan. Upaya koordinasi pelaksanaan program yang dilakukan pemerintah sering terhambat oleh tipe perusahaan yang sulit untuk diakses informasinya.

Temuan penelitian di lapangan menunjukan praktik-praktik pelaksanaan CSR oleh Perusahaan besar swasta dipengaruhi oleh beberapa kondisi, sebagai berikut :

I) Sesuai regulasi yang berlaku dan filosofis bahwa CSR merupakan bentuk kepedulian social perusahaan terhadap lingkungan dan masyarakat sekitarnya, maka selama ini perencanaan program kegiatan CSR dilakukan sendiri oleh perusahaan tanpa melibatkan secara nyata dan sistimatik pemerintah dan masyarakat setempat sebagai stakeholder. Kondisi ini memunculkan situasi dimana program yang ditawarkan oleh perusahaan tidak selamanya sesuai dengan kebutuhan dan atau sejalan dengan program pembangunan pemerintah setempat.

2) Terkait kondisi tersebut, didapati bahwa perencanaan dan pelaksanaan program CSR Perusahaan tidak secara sistimatik diwajibkan memberikan laporan secara berkala kepada Pemerintah setempat (misalnya Kecamatan). Seluruh stakeholder menyatakan bahwa mereka tidak tahu secara pasti program kegiatan CSR Perusahaan yang direncanakan maupun dilakukan, kecuali terkadang mendapatkan informasi yang sifatnya insidentil.

3) Perusahaan tidak memiliki kewajiban untuk membuat laporan pelaksanaan CSR kepada pemerintah daerah setempat (Desa dan Kecamatan), sehingga menyulitkan koordinasi dan sinkronisasi program antara pemerintah dan perusahaan. Sedangkan upaya koordinasi pelaksanaan program CSR yang dilakukan pemerintah seringkali mengalami hambatan teknis. 
4) Menyangkut besaran dana CSR perusahaan sulit untuk diakses informasinya. Perusahaan cenderung enggan menampilkan nilai dana CSR yang dialokasikan. Hal ini terjadi karena berdasarkan regulasi tidak terdapat ukuran pasti jumlah dana yang harus dianggarkan perusahaan dalam kegaiatan CSR. Jumlah yang patut dan layak untuk kegiatan CSR mengakibatkan besaran dana yang dikeluarkan perusahaan tidak sama antara yang satu dengan lainnya. Perusahaan perkebunan besar sawit umumnya adalah Perseroan Terbatas non BUMN yang hanya dikenakan kewajiban melakukan tanggung jawab social perusahaan namun tidak ada aturan dari pemerintah tentang berapa besaran dana CSR yang harus dikeluarkan. Besar kecilnya dana CSR yang dikeluarkan tergantung kehendak perusahaan itu sendiri. Jika perusahaan sangat peduli terhadap tanggung jawab sosialnya, maka besaran dana CSR tentu besar, namun jika kurang peduli maka besaran dana CSR yang dikeluarkan perusahaan juga sedikit.

5) Keberadaan Forum CSR yang telah ada selama ini cenderung mati suri dan kurang berperan mengoptimalkan program kegiatan CSR dalam rangka menunjang pembangunan. Beberapa pengusaha menyampaikan seharusnya Forum CSR ini merupakan ranahnya perusahaan, dimana melalui forum ini mereka dapat saling berkomunikasi sesame perusahaan dan dengan stakeholder. Ketidaksepahaman terhadap keberadaan Forum CSR yang terjadi menyebabkan Perusahaan kurang tertarik aktif di dalamnya.

6) Kendala lain dalam pelaksanaan program CSR adalah bahwa pihak perusahaan terkesan kurang percaya untuk memberikan pendanaan langsung kepada pemerintah. Kekurang percayaan itu dapat dipahami karena ketiadaan badan pelaksana yang bertugas mengelola CSR serta tidak adanya petunjuk teknis payung hukum yang mengaturnya.. Demikian juga pihak pemerintah, belum ada regulasi yang mengatur tentang pengelolaan tingkat daerah akan kesulitan untuk mengelola dana CSR perusahaan. Pola sharing dana juga mengalami kendala karena pola keuangan seperti itu sulit untuk dipertanggungjawabkan. Rentan untuk bersinggungan dengan pihak aparat hukum.

\section{KESIMPULAN}

Sebagian besar perusahaan perkebunan swasta di Kabupaten Kotawaringin Timur telah melaksanakan program CSR, memiliki pandangan yang positif terhadap CSR, serta memiliki konsep CSR-nya masingmasing. Namun demikian dalam pelaksanaannya masih secara parsial, belum tepat sasaran, belum transparan terkait pelaporan program. Dalam koordinasi dan sinkronisasi dengan program pemerintah daerah masih belum terjalin baik.

Kebijakan CSR oleh Pemerintah Kabupaten Kotawaringin Timur dalam tataran implementasi masih lemah. $\mathrm{Hal}$ ini diakibatkan kurang adanya kesepahaman antar stakeholder dalam memahami tata kelola CSR yang baik dan berkelanjutan. Amanat dari Peraturan Daerah No.21 tahun 2014 Kabupaten Kotawaringin Timut tentang CSR adalah pembentukan Forum CSR. Namun demikian dalam perjalanannya Forum CSR belum bisa bergerak secara fleksibel karena keterbatasan program kerja dan anggaran. Sehingga Forum CSR sampai dengan sekarang belum bisa secara optimal menjembatani pemerintah dengan pihak perusahaan terkait tata kelola program CSR.

Faktor pendukung dalam pelaksanaan program CSR di Kabupaten Kotawarigin timur adalah perangkat regulasi yang sudah lengkap, seperti Peraturan Daerah 
No.2I Tahun 2014, Peraturan Bupati sampai terbentukya Forum CSR. Namun demikian dalam realitasnya eksekusi teknis terkait Perda tersebut masih lemah dan eksistensi Forum CSR masih terkendala program kerja ataupun anggaran. Di sisi lain terdapat beberapa faktor penghambat yang mempengaruhi pelaksanaan program CSR oleh perusahaan besar swasta, antara lain : pemahaman masyarakat yang masih rendah tentang CSR, program CSR belum sistematis dan sejalan dengan kebutuhan pembangunan daerah, belum terdapat system pelaporan perencanaan dan pelaksanaan CSR secara berkala dan transparan. Sementara pola sharing dana berupa uang masih sulit untuk dipertanggungjawabkan. Oleh karena itu, akan lebih baik jika CSR disinergikan dengan perencanaan daerah kemudian diberikan kepada pemerintah daerah berupa hibah bentuk fisik.

\section{REFERENSI}

Astri, H. 2012. The Influence of Corporate Social Responsibility Toward the Improvement of Quality of Life in Indonesia. Pusat Pengkajian, Pengolahan Data dan Informasi (P3DI) Sekretariat Jenderal DPR RI.

Azheri, B. 201I. Corporate Social Responsibility: Dari Voluntary Menjadi Mandatory. Jakarta: Rajawali Press.

Bank, W. 2006. From Curse to Blessing Natural Resources and Institutional Quality. Washington, DC: The World Bank.

Dahlsrud, A. 2008. How Corporate Social Responsibility is Defined: an Analysis of 37 Definitions. Corporate Social Responsibility and Environmental Management No. 15.

Epstein, M. J. 2008. Making Sustainability Work Best Practices in Managing and Measuring Corporate Social, Environmental and Economic Impact. Green Leaf Publishing.
Fox, T. 2004. Corporate Social Responsibility and Development: In the quest of an agenda development, 47 (3). 29-36.

Jalal. 20I I. Pembangunan Berkelanjutan, Corporate Social Responsibility dan Pengembangan Masyarakat. Jakarta: Lingkar Study CSR Indonesia.

Kiroyan, N. 2009. CSR Compliance and Business Opportunities. Materi presentasi disampaikan pada pertemuan Amerika Chamber in Indonesia.

Kotler, P., \& Nancy, L. 2005. Corporate Social Responsibility, Doing the most Good for Your Company and Your Cause. Canada: John Willey \& Sons Inc.

Moon, J., \& Vogel, D. 2009. Corporate Social Responsibility, Government and Civil Society. New York: Oxford University Press.

O'Riordan, Fairbrass, L., \& Jenny. 2006. Corporate Social Responsibility (CSR) Models and Theories in Stakeholder Dialogue. Paper Presentation In Corporate Responsibility Research Conference.

Prajarto, N., \& Radityo, M. 2012. Lihatlah CSR-nya. Yogyakarta: FISIPOL UGM.

Radyati, M. 2008. CSR Untuk Pemberdayaan Ekonomi Lokal. Jakarta: Indonesia Business Links.

Sachs, J., \& Warner. 200I. The Curse of Natural Resources. European Economic Review, 45 (46), 827-838.

Saidi, Z., \& Abidin, H. 2004. Menjadi Bangsa Pemurah: Wacana dan Praktek Kedermawanan Sosial di Indonesia. Jakarta: Piramedia.

Steurer, R. 2010. The Role of Governments in Corporate Social Responsibility: Characterising Public Policies on CSR in Europe. Institute of Forest, Environmental and Natural Resource Policy, Discussion Paper 2-20I0.

Suharto, E. 2006. Membangun Masyarakat Memberdayakan Rakyat: Kaiam Strategis Pembangunan Kesejahteraan Sosial dan Pekerja Sosial. Bandung: Refika Aditama. 
Tania, S. 2012. Corporate Social Responsibility di Indonesia: Prinsip dan Aplikasi. Yogyakarta: FISIPOL UGM.

Visser, W. 2010. CSR 2.0 and the New DNA of Business. Journal of Business Systems, Governmence and Ethics Vol. 5, No. 3, 7.

Visser, W. 201 I. The Age of Responsibility: CSR 2.0 and the new DNA of Business. Journal of Business System.

Wibisono, Y. 2007. Membedah Konsep dan Aplikasi CSR. Gresik: Fascho Publishing. 